\title{
Reduction of Prochiralic Ketones by NAD(H)- dependent Alcohol Dehydrogenase in Membrane Reactor
}

\author{
By Michele Vitolo* \\ Ester Junko Yoriyaz ${ }^{\dagger}$
}

Chiral alcohols are intermediates of organic synthesis protocols for attaining flavors, pheromone, phytohormone and therapeutic molecules. This work dealt with the conversion of acetophenone and hexanone intol-phenyl ethanol and 2-hexanol, respectively, by $N A D(H)$-dependent alcohol dehydrogenase $(A D H)$ in a membrane reactor $(M R)$ operated in a continuous regimen, there being at the bottom a nanofiltration membrane (MWCO 500Da). The conversions, in which the ethanol was employed as a co-substrate, were carried out at 100rpm, a feeding rate of $5 \mathrm{~mL} / \mathrm{h}$, $A D H(150 U)$, temperature $\left(30^{\circ} \mathrm{C}\right), \mathrm{pH}(8.8)$, initial substrate concentration (30mM) and $\beta-N A D / \beta-N A D H(0.9 m M)$. The ADH activity as well as the factors affecting it (temperature and initial substrate concentration) was measured through the consumption or formation of $\beta-N A D H$ at $340 \mathrm{~nm}$. The optimum temperature for $5 \mathrm{~min}$ of reaction was $45 \mathrm{oC}$. The Michaelis-Menten constant related to the action of ADH on $\mathrm{NADH}$, acetophenone and 2-hexanone were $(K M) N A D H=0.177 \mathrm{mM}$, $(K M)$ acetophenone $=1.04 \mathrm{mM}$ and $(K M) 2$ hexanone $=1.44 \mathrm{mM}$. Along the reaction, the NAD/NADH regeneration occurred and the membrane used retained both the $A D H$ and the coenzymes (NAD; NADH) inside the reactor. Finally, the acetophenone/1-phenylethanol and 2-hexanone/2-hexanol conversions through the $M R$ were $60 \%$ and $30 \%$, respectively.

Keywords: Membrane reactor, Alcohol dehydrogenase, 2-hexanol, 1-phenyl ethanol

\section{Introduction}

During the last few decades, the interest in using biocatalysts has been growing. The reason is that they convert a specific molecule (the substrate) into a desired bio-product at a high rate under mild conditions, often generating, non-toxic effluents into the environment. The possibility of carrying out coupled reactions - two or more enzymes acting in sequence, two enzymes acting in opposite directions (Andreotti et al., 2010) and one coenzymedependent enzyme acting in opposite directions according to the $\mathrm{pH}$ of the reaction medium (Riebel, 2003) - constitutes a valuable approach to the enzyme technology.

${ }^{*}$ Professor, University of São Paulo, Brazil.

†Post-doctoral Fellow, University of São Paulo, Brazil. 
Chiral alcohols are intermediates of organic synthesis protocols for attaining among other flavors, pheromone, phytohormone and therapeutic molecules (Goldberg, 2007).

The reversible conversion of ketones/aldehydes into primary and/or secondary alcohols can be achieved by using the yeast alcohol dehydrogenase $(\mathrm{ADH})$, an enzyme which requires the NAD/NADH coenzymes as cosubstrates. However, the coenzymes are expensive substances which must be regenerated during the catalysis, if an effective use of ADH is envisaged (Lutz et al., 2006). Furthermore, the coenzyme regeneration avoids the eventual inhibition caused by the product on its actuation as a co-substrate (Van der Donk and Zhao, 2003). An alternative would be the use of a whole yeast cell in order to take advantage of the natural presence of coenzymes and ADH inside the cell. Nevertheless, the catalytic performance of an intact cell is quite low due mainly to the hindrance posed by both the cell wall and the plasmatic membrane to the in/out diffusion of substrates and products. The whole-cell catalyst leads to the occurrence of undesirable side reactions and the attainment of low volumetric productivity as well. The approaches envisaged for regenerating the coenzyme would thus be either by coupling two enzyme catalyses (one NAD and the other NADH-dependent, for instance) or by one enzyme (such as yeast $\mathrm{ADH}$ ) which has its oxidation $(\mathrm{pH} \leq 7.0)$ and reduction $(\mathrm{pH} \geq 8.0)$ capabilities exchanged through the $\mathrm{pH}$ variation of the reaction medium (Wildeman at al., 2007; Findrik et al., 2007).

The type of reactor to be chosen must fulfill two pre-conditions which are both retaining the coenzyme molecule (MW near 700Da) and allowing its prompt regeneration.

Among all kinds of reactors available - mainly a packed- or fluidized-bed reactor in which the coenzyme might be obligatorily in the immobilized form -, the membrane reactor (MR) seems to be the most adequate because it can be operated both in a discontinuous or a continuous mode as well as with the coenzyme in a soluble or an immobilized form (Curcio et al., 2002).

The MR is a variant of the continuous stirred tank reactor (CSTR) in which an ultra (UF) (pore diameter: 0.001 a $0.1 \mu$ ) or nanofiltration (NF) (pore $<2 \mathrm{~nm}$ ) membrane was coupled. It can be designed either by connecting in series the CSTR to a membrane container (two-module-MR) or by adapting the membrane to the bottom of the CSTR as in a stirred ultrafiltration cell (onemodule-MR). Although the two-module-MR is the preferred one - in the literature, there are several processes described in which L-amino acids, alcohols and R-hydroxyacids are attained by using NAD(P)H-dependent dehydrogenases (Wildeman et al., 2007; Findrik et al., 2007) -, the onemodule-MR has some favorable operational characteristics such as a homogeneous catalysis, the use of two or more enzymes (multienzymatic reactions), a high activity per unit of volume and the absence of diffusion effects on the overall transit of substances in/out of the reactor (Tomotani and Vitolo, 2007). The employment of membrane reactors since 2000 has led to the development of several processes which among others are: the hydrolysis of casein and hemoglobin (Curcio et al., 2002); the hydrolysis of sucrose (Yoriyaz 
and Vitolo, 2014); the synthesis of cyclodextrins (Slominska et al., 2002), fructooligosaccharydes (Sheu at al., 2002), cathecol (Boshoff et al., 2003) and esters (Lozano et al., 2004); a wastewater and industry effluent treatment (Chen, 2008; Martin-Pascual et al., 2015; Ghalavand et al., 2015).

In this work, the feasibility of using $\operatorname{NAD}(\mathrm{H})$-dependent alcohol dehydrogenase $(\mathrm{ADH})$, attained from Saccharomyces cerevisiae, as a means of simultaneous regeneration of coenzymes $(\beta-N A D \leftrightarrow \beta-N A D H)$ as well as obtaining chiral alcohols (1-phenylethanol and 2-hexanol) from prochiral ketones (acetophenone and 2-hexanone) by using a one-module membrane reactor (MR) coupled with a NF-membrane (MWCO 500Da) were studied.

\section{Materials and Methods}

\section{Materials}

Alcohol dehydrogenase (ADH - E.C.1.1.1.11) from Saccharomyces cerevisiae and the coenzymes ( $\beta-\mathrm{NAD}$ and $\beta-\mathrm{NADH})$ were purchased from Sigma, St. Louis, USA. The NF-membrane (MWCO 500Da) was kindly donated by Bioengineering ${ }^{\circledR}$ AG. All of the other chemicals used were also of the highest analytical grade.

\section{Methods}

Standard Assay for Measuring ADH Activity

$\mathrm{ADH}$ activity was assayed spectrophotometrically at $45^{\circ} \mathrm{C}$ by measuring the change in absorbance of $\mathrm{NADH}$ (formed or consumed, respectively, from the oxidation or reduction reaction) at 340nm using a Beckman DU 640 spectrometer equipped with a Peltier effect-controlled temperature cuvette holder (Taraboulsi-Jr. et al., 2014).

The standard assay for the coenzyme oxidation reaction was carried by adding $10 \mu \mathrm{L}$ of $\mathrm{ADH}(0.75 \mathrm{U} / \mathrm{mL}), 440 \mu \mathrm{L}$ of $10 \mathrm{mM}$ phosphate buffer $(\mathrm{pH}$ 7.0), $500 \mu \mathrm{L}$ of $10 \mathrm{mM} 2$-hexanone or acetophenone, $50 \mu \mathrm{L}$ of $2 \mathrm{mM} \beta-\mathrm{NADH}$ and $10 \mu \mathrm{L}$ of the mixture [0.1\% (w/v) of BSA and $10 \%(\mathrm{v} / \mathrm{v})$ of DMSO]. In the blank tube, all reagents cited, except for the ADH solution was introduced.

The standard assay for the coenzyme reduction reaction was carried by adding $50 \mu \mathrm{L}$ of $\mathrm{ADH}(0.75 \mathrm{U} / \mathrm{mL}), 50 \mu \mathrm{L}$ of $10 \mathrm{mM}$ phosphate buffer $(\mathrm{pH} 8.8)$, $500 \mu \mathrm{L}$ of $10 \mathrm{mM}$ 2-hexanol or 1-phenylethanol, $400 \mu \mathrm{L}$ of $2 \mathrm{mM} \beta-\mathrm{NAD}$ and $50 \mu \mathrm{L}$ of the mixture [0.1\% (w/v) of BSA and $10 \%(\mathrm{v} / \mathrm{v})$ of DMSO]. In the blank tube, all reagents cited, except the ADH solution was introduced.

The enzyme activity, expressed as $\mathrm{U} / \mathrm{mL}$, was calculated through the equation:

$$
(\mathrm{U} / \mathrm{mL})_{\mathrm{ADH}}=\text { V.f. }\left[\left(\triangle \mathrm{Abs}_{340} / \mathrm{min}\right)_{\text {test }}-\left(\triangle \mathrm{Abs}_{340} / \mathrm{min}\right)_{\text {blank }}\right] \div\left[\mathrm{a}_{\mathrm{m} . \mathrm{V}}\right]
$$

Where: $\mathrm{V}=$ reaction volume; $\mathrm{f}=$ dilution factor; $\left(\triangle \mathrm{Abs}_{340} / \mathrm{min}\right)_{\text {test }}=$ absorbance variation of the test tube during 1min reaction; $\left(\triangle \mathrm{Abs}_{340} / \mathrm{min}\right)_{\text {blank }}$ 
$=$ absorbance variation of the blank tube during 1 min reaction; $\mathrm{a}_{\mathrm{m}}=6.22 \mathrm{mM}^{-}$ ${ }^{1} . \mathrm{cm}^{-1} ; \mathrm{v}=$ volume of ADH solution.

One unit of ADH represented $1 \mu \mathrm{mol}$ of $\beta$-NADH produced or consumed per minute at $45^{\circ} \mathrm{C}$, on a basis of an absorption coefficient of $6.22 \mathrm{mM}^{-1} . \mathrm{cm}^{-1}$ for $\beta-\mathrm{NADH}$ at $340 \mathrm{~nm}$.

\section{Characterization of Alcohol Dehydrogenase}

The $\mathrm{pH}$, temperature and substrate concentration of the standard reaction test related to $\mathrm{ADH}$ were changed one by one at the intervals cited in the following sections.

Effect of $\mathrm{pH}$ and the Concentration of the Buffer on ADH Activity and Stability

The effect of $\mathrm{pH}$ on the activity and stability of $\mathrm{ADH}$ was always determined at $45^{\circ} \mathrm{C}$ by mixing the enzyme with buffer solutions at a fixed $\mathrm{pH}$ (7.0, 7.5, or 8.8) (Andreotti et al., 2010). The buffer used was $10 \mathrm{mM}$ or $50 \mathrm{mM}$ phosphate buffer for all $\mathrm{pH}$ studied. The stability against $\mathrm{pH}$ was evaluated by measuring the residual activity of $\mathrm{ADH}$ in samples taken at each $2 \mathrm{~h}$ up to $24 \mathrm{~h}$ of enzyme-buffer contact at $45^{\circ} \mathrm{C}$.

\section{Effect of Temperature on Activity and Stability}

The effect of the temperature on enzyme activity was evaluated by varying the temperature of the standard $\mathrm{ADH}$ assay between $25^{\circ} \mathrm{C}$ and $50^{\circ} \mathrm{C}$. The evaluation of the $\mathrm{ADH}$ stability against temperatures of $30^{\circ}, 35^{\circ}, 40^{\circ}, 45^{\circ}$ and $50^{\circ} \mathrm{C}$ was carried out by leaving a $10 \mathrm{mM}$ phosphate buffer $(\mathrm{pH} 7.0)$ solution of $\mathrm{ADH}(0.75 \mathrm{U} / \mathrm{mL})$ at each temperature for a time interval of $10-1440 \mathrm{~min}$. The residual ADH activity was measured as described above.

\section{Effect of the Initial Substrate Concentration}

The ADH activity was measured against an initial concentration of acetophenone, 2-hexanone, ethanol or $\beta$-NADH. The correspondent kinetic constants were calculated by applying the conventional Lineweaver-Burk method.

\section{Batch Bioconversion}

In a $100 \mathrm{~mL}$-flask, $25 \mathrm{~mL}$ of $10 \mathrm{mM}$ acetophenone or 2-hexanone, $5 \mathrm{~mL}$ of $15 \mathrm{mM} \beta-\mathrm{NADH}, 50 \mathrm{~mL}$ of $10 \mathrm{mM}$ phosphate buffer $(\mathrm{pH} 7.0)$ and $2 \mathrm{~mL}$ of $\mathrm{ADH}$ buffered solution (340U) were introduced. The reaction was carried out at $30^{\circ} \mathrm{C}$ for $30 \mathrm{~min}$. The 1-phenyl ethanol or 2-hexanol formed was measured by the method of potassium dichromate (Isarankura-Na-Ayudhya, 2007). Aliquots were removed every $5 \mathrm{~min}$ for measuring the alcohol formed.

\section{Continuous Bioconversion}

In a $10 \mathrm{~mL}-\mathrm{membrane}$ reactor coupled with a 500Da NF-membrane, $10 \mathrm{~mL}$ of aqueous solution containing $1 \mathrm{mM} \beta-\mathrm{NADH}$ and $\mathrm{ADH}$ (150U) was introduced. The reactor was fed with the buffered solution $(\mathrm{pH} 7.0)$ of $10 \mathrm{mM}$ 
substrate (acetophenone or 2-hexanone) at a feeding rate of $2 \mathrm{~mL} / \mathrm{h}$. The overall duration of the continuous feeding was $96 \mathrm{~h}$ at $30^{\circ} \mathrm{C}$ and $100 \mathrm{rpm}$. Samples were taken every $2 \mathrm{~h}$ for analytical purposes. The feeding of the reactor along the reaction was made by alternating the ketone solution with a $10 \mathrm{mM}$ ethanol buffered solution ( $\mathrm{pH} 8.8$ ), in order to promote $\beta-\mathrm{NADH} / \beta-\mathrm{NAD}$ recycling along the overall continuous process. The membrane reactor employed was purchased from Bioengineering AG (Wald, Germany). It is a 316-L stainless steel cylinder, whose bottom has an inlet and an outlet for the external water bath for the temperature control. The reactor employs a $63 \mathrm{~mm}$ diameter UF- or NF-membrane, it can be sterilized as well (autoclave up to $134^{\circ} \mathrm{C}$ for $30 \mathrm{~min}$ ) and resists high temperatures (up to $150^{\circ} \mathrm{C}$ ) and corrosion by most substances (except strong acids, $\mathrm{pH}<1.0$; and alkalies, $\mathrm{pH}>12.0$ ). It supports pressure up to 6bar and can be coupled to a dosing pump, a pressure probe, a sterile filter and a bubble trap.

The membrane integrity along the reaction was monitored by measuring the protein and coenzyme presence in the outlet solution (Taraboulsi-Jr. et al., 2014). The absence of protein and coenzyme was taken as the criterion for membrane integrity.

\section{Analytical Techniques}

Measurement of Carbonyl Compounds with 2,4-dinitro-phenylhydrazine

The determination was based on the approach proposed by Purnendu et al. (1994). The reagent solution was prepared by dissolving $0.1 \mathrm{~g}$ of 2,4-dinitrophenylhydrazine and $0.5 \mathrm{~mL}$ of concentrated $\mathrm{HCl}$ in $100 \mathrm{~mL}$ of acetic acid. The determination of acetaldehyde, 2-hexanone or acetophenone was carried out by mixing $1 \mathrm{~mL}$ of the sample with $5 \mathrm{~mL}$ of reagent and leaving the mixture at room temperature for $1 \mathrm{~h}$. The intensity of the color formed was read by a spectrophotometer at $480 \mathrm{~nm}$. The absorbance was compared to the correspondent standard curve made with acetaldehyde, 2-hexanone or acetophenone (Figure 4).

\section{Measurement of Alcohols with Potassium Dichromate}

The determination was based on the method proposed by Isarankura-NaAyudhya, (2007). The reagent solution was prepared by dissolving $7.4 \mathrm{~g}$ of potassium dichromate in $190 \mathrm{~mL}$ of distilled water followed by the addition of $60 \mathrm{~mL} 0.5 \mathrm{M}$ sulfuric acid solution. The reagent was left resting for $48 \mathrm{~h}$ before use. The determination of ethanol, 2-hexanol or 1-phenylethanol was carried out by mixing $1 \mathrm{~mL}$ of the sample with $4 \mathrm{~mL}$ of distilled water and $1 \mathrm{~mL}$ of reagent and leaving the mixture at room temperature for $10 \mathrm{~min}$. The intensity of the color formed was read by spectrophotometer at $590 \mathrm{~nm}$. The absorbance was compared to the correspondent standard curve made with ethanol, 2hexanol or 1-phenylethanol (Figure 4). 
Vol. 2, No. 3 Vitolo et al.: Reduction of Prochiralic Ketones by NAD(H)-dependent...

\section{Protein Determination}

Protein was determined based on the difference between UV absorbance measured at $215 \mathrm{~nm}$ and $225 \mathrm{~nm}$, using bovine serum albumin (BSA, from Sigma, St. Louis, USA) as a standard (Tomotani and Vitolo, 2007).

Cofactor Determination

Both cofactors, $\beta$-NAD and $\beta$-NADH, were determined spectrophotometrically at 260 and $340 \mathrm{~nm}$, respectively (Taraboulsi-Jr. et al., 2014).

\section{Results}

The ADH activity was measured against both acetophenone $\left[0.15\left(\mathrm{ABS}_{340 \mathrm{~nm}}\right) / \mathrm{min}\right]$ and 2-hexanone $\left[0.11\left(\mathrm{ABS}_{340 \mathrm{~nm}}\right) / \mathrm{min}\right]$ (Figure 1). The ADH activity was also measured against ethanol $\left[0.090\left(\mathrm{ABS}_{340 \mathrm{~nm}}\right) / \mathrm{min}\right]$ because it was used as an auxiliary substrate for converting the cited ketones into the respective chiralic alcohols through the membrane reactor.

Figure 1. Alcohol Dehydrogenase Activity Measured by using Ethanol (•), Acetophenone (-) and 2-hexanone (A) as Substrates. The Least-square Linear Regression Equations for Ethanol, Acetophenone and 2-hexanone were, Respectively, $Y_{E}=9 \times 10^{-2} . t+0.72(r=0.997), Y_{A}=-0.15 . t+0.98(r=0.994)$ and $Y_{H}=-0.11 . t+0.87(r=0.996)$



The effect of $\mathrm{pH}(7.0,7.5$ or 8.8$)$ and the phosphate buffer concentration $(10 \mathrm{mM}$ or $50 \mathrm{mM})$ on the ADH activity are shown in Table 1 . 
Table 1. Effect of $p H$ and Phosphate Buffer Concentration on the Alcohol Dehydrogenase Activity (U/min) Measured against Acetophenone $\left(A D H_{A}\right)$ and 2-hexanone $\left(\mathrm{ADH}_{H}\right)$ as Substrates

\begin{tabular}{|c|c|c|}
\hline \multirow{2}{*}{$\mathbf{p H}$} & \multicolumn{2}{|c|}{ ADH activity (U/min) } \\
\cline { 2 - 3 } & $10 \mathrm{mM}$ & $50 \mathrm{mM}$ \\
\hline 7.0 & $* 645 / 550$ & $807 / 686$ \\
\hline 7.5 & $641 / 545$ & $844 / 717$ \\
\hline 8.8 & $502 / 427$ & $509 / 433$ \\
\hline
\end{tabular}

*First and second values refer to the $\mathrm{ADH}_{\mathrm{A}}$ and $\mathrm{ADH}_{\mathrm{H}}$, respectively

Considering that the $\mathrm{ADH}$ activity has high sensitivity to the $\mathrm{pH}$ variation of the reaction medium - at $6.6 \leq \mathrm{pH} \leq 7.0$, it catalyses the oxidation of the coenzyme and reduction of the carbonyl compound whereas at $\mathrm{pH}>7.0$, it promotes the reduction of coenzyme and the oxidation of the alcohol - there was no need to evaluate the activity against a larger $\mathrm{pH}$ interval. Thereby, the $\mathrm{pH}$ was set at 7.0 and 7.5 and the temperature of the reaction varied between $25^{\circ} \mathrm{C}$ and $50^{\circ} \mathrm{C}$ (Figure 2).

Figure 2. Variation of Alcohol Dehydrogenase Activity against the Temperature using Acetophenone [pH $7.0(\bullet)$ and $\mathrm{pH} 7.5(\mathrm{o})]$ and 2-hexanone [pH $7.0(\square)$ and $7.5(\square)$ as the Substrates. The Overall Reaction Time was Equal to $5 \mathrm{~min}$

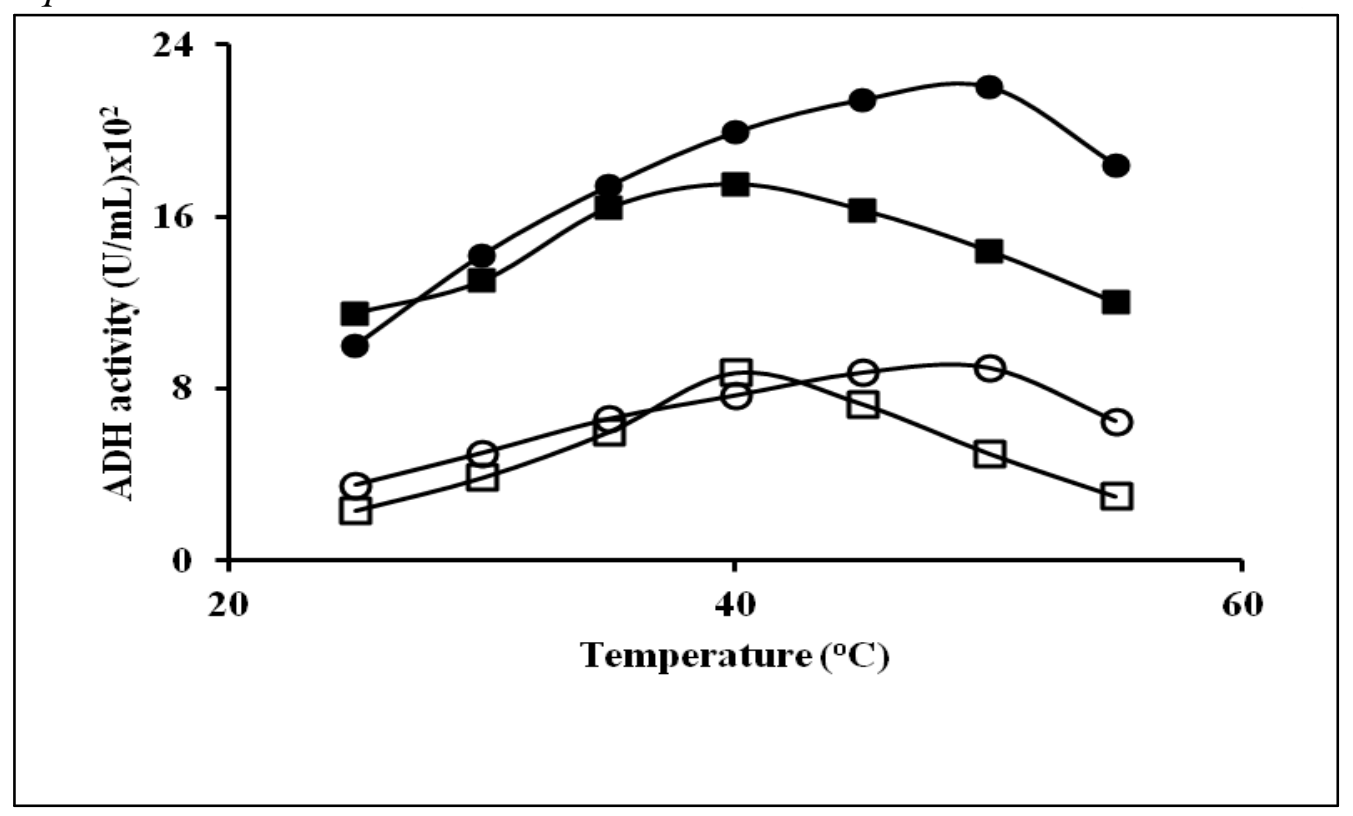

The stability of $\mathrm{ADH}$ for $24 \mathrm{~h}$ was made leaving the buffered enzyme solution $(1000 \mathrm{U} / \mathrm{mL})$ at $\mathrm{pH} 7.0$ and temperatures of $40^{\circ} \mathrm{C}$ and $50^{\circ} \mathrm{C}$. The residual $\mathrm{ADH}$ activity was measured against 2-hexanone and acetophenone as substrates (Figure 3). 
Vol. 2, No. 3 Vitolo et al.: Reduction of Prochiralic Ketones by NAD(H)-dependent...

Figure 3. Variation of the Residual Activity of ADH Dissolved in 50mM Phosphate Buffer ( $\mathrm{pH}$ 7.0), the Solution being maintained at $40^{\circ} \mathrm{C}$ and $50^{\circ} \mathrm{C}$ for 24h. The Enzyme Activity was Measured using 2-hexanone $\left[40^{\circ} \mathrm{C}(\bullet)\right.$ and $50^{\circ} \mathrm{C}$ (-)] and Acetophenone $\left[40^{\circ} \mathrm{C}(\Delta)\right.$ and $\left.50^{\circ} \mathrm{C}(\bullet)\right]$

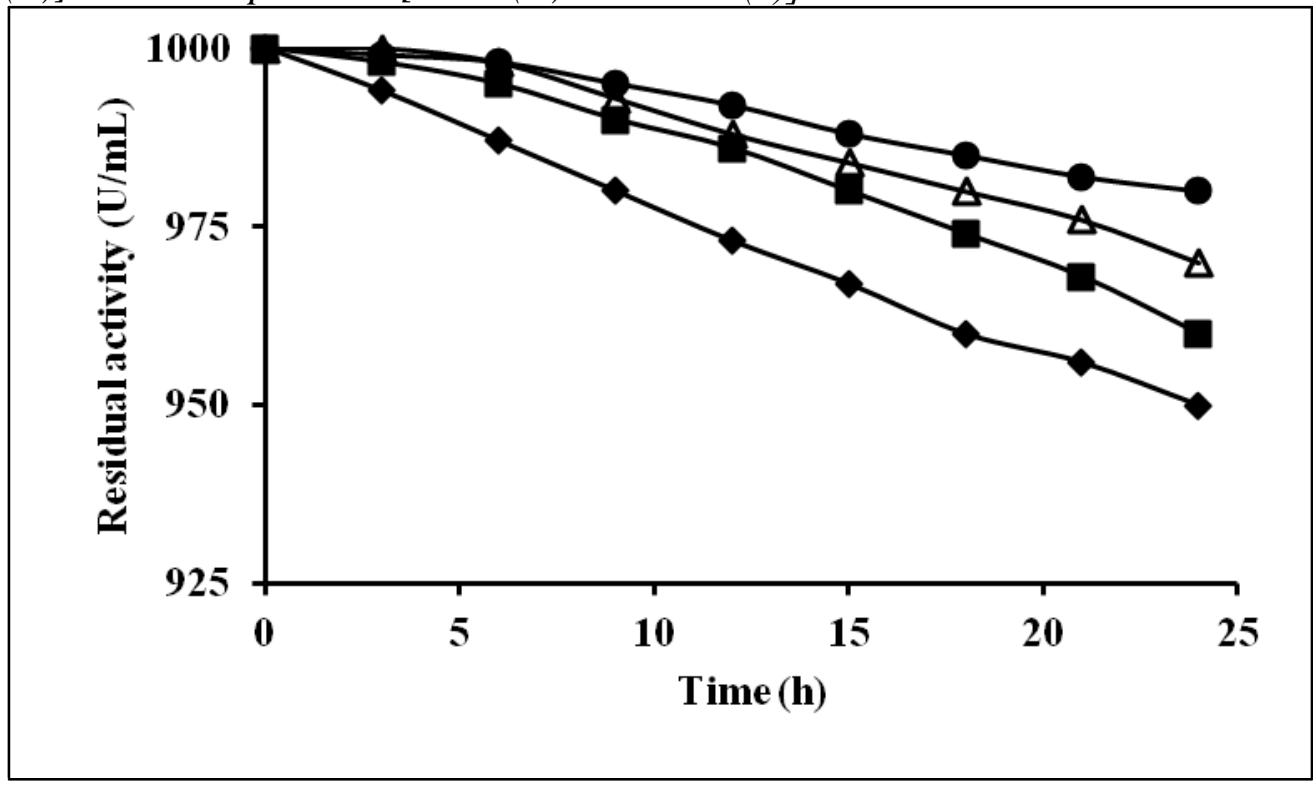

The effect of initial concentrations of $\beta$-NADH, 2-hexanone and acetophenone on ADH activity were determined (Table 2) and the respective kinetic constants $\left(\mathrm{K}_{\mathrm{M}}\right.$ and $\left.\mathrm{V}_{\max }\right)$ calculated through the Lineweaver-Burk's method.

Table 2 ADH Activity against Initial Concentrations of $\beta-N A D H$, Acetophenone and 2-hexanone

\begin{tabular}{|c|c|c|c|c|c|}
\hline $\begin{array}{c}\boldsymbol{\beta}-\mathbf{N A D H} \\
(\mathbf{m M}) \mathbf{x 1 0} \mathbf{3}^{\mathbf{3}}\end{array}$ & $\begin{array}{c}\mathbf{V}_{\text {nadh }} \\
(\mathbf{U}) \mathbf{x 1 0}\end{array}$ & $\begin{array}{c}\text { Acetophenone } \\
(\mathbf{m M}) \mathbf{1 0} \mathbf{2}^{\mathbf{3}}\end{array}$ & $\begin{array}{c}\mathbf{v}_{\text {acetophenone }} \\
(\mathbf{U}) \mathbf{x 1 0}\end{array}$ & $\begin{array}{c}\text { 2-hexanone } \\
(\mathbf{m M}) \mathbf{x 1 0} \mathbf{2}^{\mathbf{4}}\end{array}$ & $\begin{array}{c}\mathbf{v}_{\text {2-hexanone }} \\
(\mathbf{U}) \mathbf{x 1 0}\end{array}$ \\
\hline 25 & 86,3 & 15 & 143 & 20 & 132 \\
\hline 50 & 154 & 30 & 329 & 40 & 235 \\
\hline 65 & 187 & 40 & 408 & 50 & 278 \\
\hline 90 & 235 & 55 & 508 & 75 & 370 \\
\hline 100 & 252 & 60 & 538 & 85 & 401 \\
\hline 130 & 295 & 80 & 639 & 100 & 443 \\
\hline 160 & 331 & 90 & 682 & 130 & 512 \\
\hline 200 & 370 & 120 & 788 & 160 & 568 \\
\hline 250 & 408 & 150 & 868 & 200 & 628 \\
\hline
\end{tabular}

Figure 4 shows the standard curves for measuring the concentration of alcohols (ethanol, 1-phenyl ethanol and 2-hexanol) and ketones (acetophenone and 2-hexanone) by using the reagents potassium dichromate and 2,4-dinitrophenylhydrazine, respectively. The color intensity of each solution was read 
through the spectrophotometer at wavelengths of 590nm (alcohols) and 480nm (ketones).

Figure 4. Standard Curves regarding the Determination of Alcohols [1Phenylethanol (o), 2-hexanol ( $\square$ ) and Ethanol ( $\Delta)$ ] and Ketones [Acetophenone (•) and 2-hexanone (-)] by using, Respectively, Potassium Dichromate and 2,4-dinitro-phenylhydrazine Reagents, whose Color Intensities of Solutions were Read at Wavelengths of 590nm and 480nm, Respectively

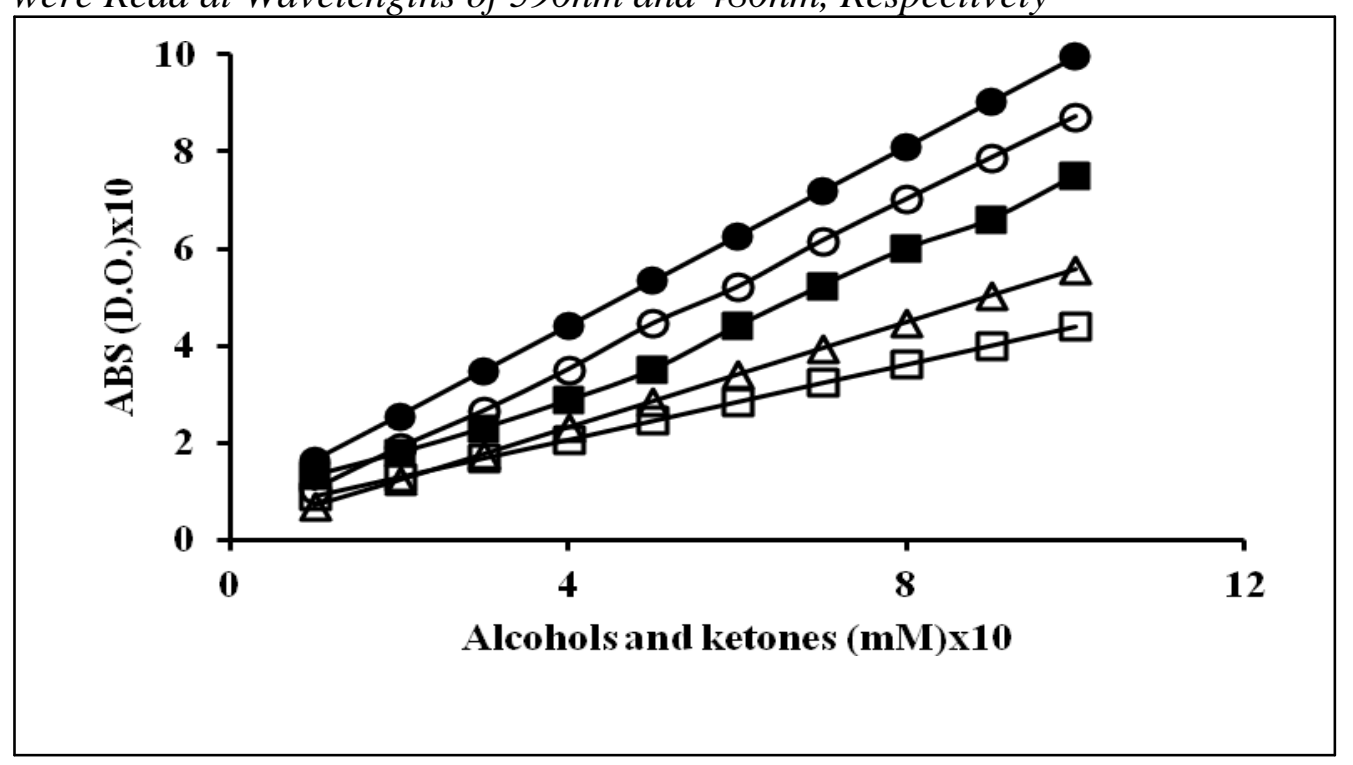

The alcohol (1-phenyl ethanol and 2-hexanol) formations and ketones consumption (acetophenone and 2-hexanone) during the batch process were shown in Figure 5.

\section{Discussion}

Figure 1 shows that the ADH yeast has a slight preference for acetophenone over 2-hexanone, insofar as the enzyme activity was about $27 \%$ higher for acetophenone than for 2-hexanone.

From Table 1, it can be seen that the concentration of the buffer, that is the ionic strength of the solution, affected the ADH activity. For instance, at $\mathrm{pH}$ 7.0 , the enzyme activity in a $50 \mathrm{mM}$ phosphate buffer was 1.25 times higher than in a $10 \mathrm{mM}$ phosphate buffer either to acetophenone or 2-hexanone used as the substrate. This is the reason by which the use of $50 \mathrm{mM}$ phosphate buffer is largely employed for ADH activity measurement (Müller, 2010). Besides, the $\mathrm{ADH}$ activity diminished as the $\mathrm{pH}$ of the medium increased independently on the type of substrate and buffer concentration. It seemed that the ADH yeast preferred catalyzing the oxidation instead of the reduction of the coenzyme. This result points to the suitability for using ADH yeast on converting prochiralic ketones into chiralic alcohols. Setting the buffer concentration at $50 \mathrm{mM}$ and using either acetophenone or 2-hexanone as the substrate, it can be 
seen that the $\mathrm{ADH}$ activity has been reduced about $37 \%$ when the $\mathrm{pH}$ was varied from 7.0 to 8.8. This result corroborates Zanon et al. (2015), which determined that the yeast $\mathrm{ADH}$ activity diminished about $40 \%$ as the $\mathrm{pH}$ was changed from 7.0 to 9.0 .

Figure 5. Conversion of Acetophenone (o) and 2-hexanone ( $\boldsymbol{\sim})$ into, Respectively, 1-phenyl ethanol (•) and 2-hexanol $(\square)$ in a Batch Process

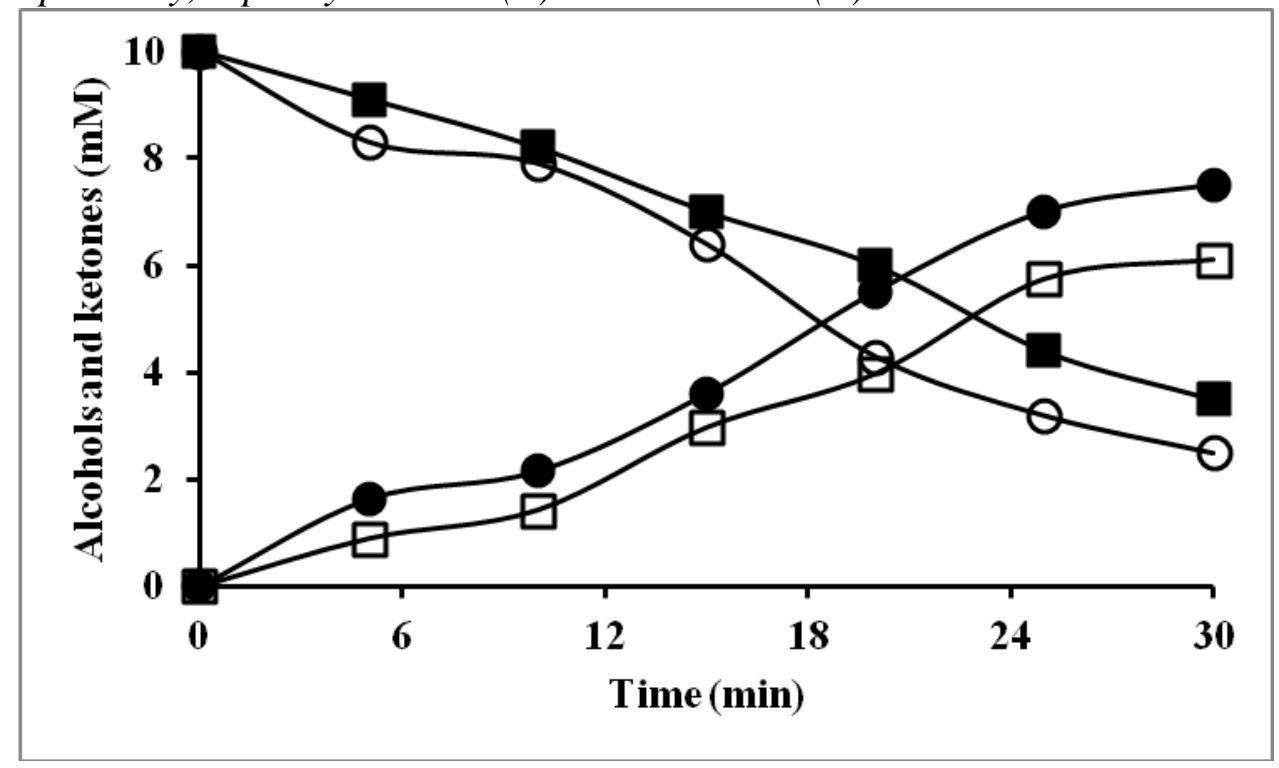

Figure 2 shows that the high $\mathrm{ADH}$ activity at $\mathrm{pH} 7.0$ and for $5 \mathrm{~min}$ of reaction occurred at temperatures of $55^{\circ} \mathrm{C}$ for acetophenone $\left(2.14 \times 10^{-1} \mathrm{U}_{\mathrm{mL}} \mathrm{mL}^{-1}\right)$ and $40^{\circ} \mathrm{C}$ for 2-hexanone $\left(8.40 \times 10^{-2} \mathrm{U}_{\mathrm{mL}} \mathrm{m}^{-1}\right)$. So, the optimal temperature under those conditions differs according to the type of prochiral ketone employed as the substrate. Besides, the $\mathrm{ADH}$ activity against both ketones diminished at least $50 \%$ at $\mathrm{pH}$ 7.5. This result, which showed a clear interaction of variables ( $\mathrm{pH}$ and temperature) on $\mathrm{ADH}$ activity, is relatively often in enzyme literature (Fullbrook, 1996). By applying the Arrhenius' method on the data presented in Figure 2, the respective activation energy $\left(\mathrm{E}_{\mathrm{a}}\right)$ to the reduction of acetophenone by $\mathrm{ADH}$ at $\mathrm{pH} 7.0\left(\mathrm{E}_{\mathrm{a}}=2.5 \mathrm{kcal} / \mathrm{mol}\right)$ and $\mathrm{pH} 7.5\left(\mathrm{E}_{\mathrm{a}}=3.8 \mathrm{kcal} / \mathrm{mol}\right)$ were calculated. The $\mathrm{E}_{\mathrm{a}}$ regarding 2-hexanone at $\mathrm{pH} 7.0$ and 7.5 were $3.3 \mathrm{kcal} / \mathrm{mol}$ and $3.7 \mathrm{kcal} / \mathrm{mol}$, respectively. Thereby, in both cases, carrying out the ketone reduction at $\mathrm{pH} 7.0$ is advisable.

After leaving the alcohol dehydrogenase for $24 \mathrm{~h}$ at $40^{\circ} \mathrm{C}$ and $50^{\circ} \mathrm{C}$, it was noted that its activity measured against acetophenone and 2-hexanone diminished along the time (Figure 3). By correlating the logarithm of the residual $\mathrm{ADH}$ activity with time, the thermal denaturing constant $\left(\mathrm{k}_{\mathrm{d}}\right)$ regarding both ketones, whose values are presented in Table 3, were calculated. Through the integrated form of Arrhenius' equation (Purich, 2010), the denaturing activation energy of alcohol dehydrogenase against acetophenone $\left(\mathrm{E}^{\prime}{ }_{\mathrm{a}}=12\right.$ $\mathrm{kcal} / \mathrm{mol})$ and 2-hexanone $\left(\mathrm{E}_{\mathrm{a}}^{\prime}=9 \mathrm{kcal} / \mathrm{mol}\right)$ used as substrates were calculated. Clearly, the structural modification suffered by the ADH molecule 
due to the temperature's increasing reflected more intensely on its capacity for reducing 2-hexanone than acetophenone. In other words, to reduce the ADH capability on reducing 2-hexanone to 2 -hexanol would require $25 \%$ less energy than for reducing acetophenone to 1-phenylethanol.

Table 3. Alcohol Dehydrogenase Thermal Denaturing Constant $\left(k_{d}\right)$ Related to Ketones Reduction into their Correspondent Alcohols

\begin{tabular}{|c|cc|}
\hline KETONE & \multicolumn{2}{|c|}{$\mathbf{k}_{\mathbf{d}}$} \\
\hline (Name) & $40^{\circ} \mathrm{C}$ & $50^{\circ} \mathrm{C}$ \\
\hline Acetophenone & -0.0016 & -0.0029 \\
\hline 2-hexanone & -0.0012 & -0.0019 \\
\hline
\end{tabular}

By applying the conventional Lineweaver-Burk's method (Purich, 2010), data presented in Table 2, the following equations were determined:

$$
\begin{array}{cc}
\left(1 / \mathrm{v}_{\text {nadh }}\right)=0.254 .\left(1 / \mathrm{S}_{\text {nadh }}\right)+1.432 & (\mathrm{r}=0.99990) \\
\left(1 / \mathrm{v}_{\text {acet }}\right)=7.40 .\left(1 / \mathrm{S}_{\text {acet }}\right)+6.32 & (\mathrm{r}=0.9997) \\
\left(1 / \mathrm{v}_{2 \text { hex }}\right)=13.32 .\left(1 / \mathrm{S}_{2 \text { hex }}\right)+9.27 & (\mathrm{r}=0.99994)
\end{array}
$$

Through the above equations, the kinetic constants for $\mathrm{NADH}\left(\mathrm{V}_{\max }=\right.$ $\left.0.698 \mathrm{U} ; \mathrm{K}_{\mathrm{M}}=0.177 \mathrm{mM}\right)$, acetophenone $\left(\mathrm{V}_{\max }=0.158 \mathrm{U} ; \mathrm{K}_{\mathrm{M}}=1.17 \mathrm{mM}\right)$ and 2-hexanone $\left(\mathrm{V}_{\max }=0.108 \mathrm{U} ; \mathrm{K}_{\mathrm{M}}=1.44 \mathrm{mM}\right)$ were calculated. As $\mathrm{K}_{\mathrm{M}}$ for acetophenone is about $19 \%$ lower than for 2-hexanone, it can be concluded that the enzyme has more affinity to acetophenone. This result corroborates the well known fact that when an enzyme acts on different substrates, there is always a preference.

Clearly the variation on the concentration of alcohols (ethanol, 1phenylethanol and 2-hexanol) and ketones (acetophenone and 2-hexanone) from $0.1 \mathrm{mM}$ to $1.0 \mathrm{mM}$ was adequately determined by using the reagents potassium dichromate and 2,4-dinitro-phenylhydrazine, respectively. According to the data shown in Figure 4, the concentrations of alcohols and ketones varied linearly with the absorbance read at $590 \mathrm{~nm}$ and $480 \mathrm{~nm}$, respectively. The least-square linear regression equations for each compound were:

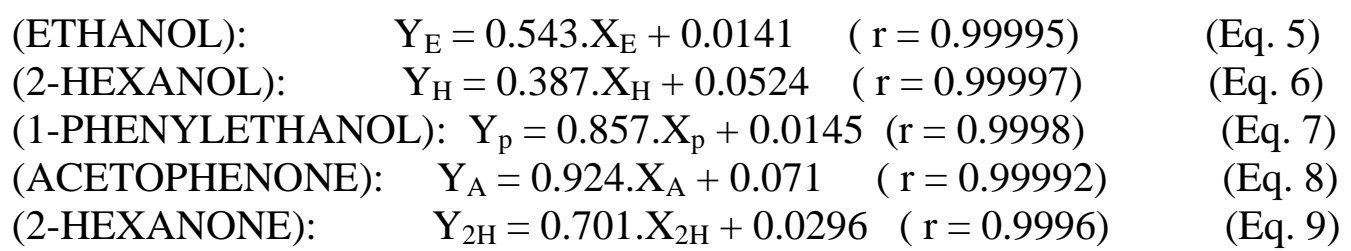

Where $Y_{E}, Y_{H}, Y_{p}, Y_{A}$ and $Y_{2 H}$ are the absorbances and $X_{E}, X_{H}, X_{p}, X_{A}$ and $\mathrm{X}_{2 \mathrm{H}}$ are the concentrations of ethanol, 2-hexanol, 1-phenylethanol, acetophenone and 2-hexanone, respectively.

By using equations 5-9, the amount formed/consumed of each substrate along the reaction catalyzed by $\mathrm{ADH}$ in batch and continuous processes were calculated. 
The conversion yields of acetophenone/1-phenylethanol and 2hexanone/2-hexanol were, respectively, $75 \%$ and $65 \%$, when the reactions have been carried out batchwise (Figure 5). Regarding to these conversions it was cited by Hummel (1990) that yields up to $80 \%$ would be achieved by using the ADH from Lactobacillus kefir.

As borne out previously, trying to carry out the ketone/alcohol reaction in the membrane reactor operated under a continuous mode is quite reasonable.

In a previous work, the possibility of recycling the coenzyme $(\beta-\mathrm{NADH} / \beta$ NAD) by employing two enzymes - one catalyzing the reduction of coenzyme (glucose 6-phosphate dehydrogenase) and the other (glutamate dehydrogenase) the reverse reaction was demonstrated (Andreotti et al., 2010). After that, the coenzyme recycling was achieved by using the substrate-coupled procedure catalyzed by the yeast $\mathrm{NAD}(\mathrm{H})$-dependent alcohol dehydrogenase (ADH), since the substrates - ethanol and acetaldehyde, in that study - were alternately fed into the membrane reactor (Tomotani and Vitolo, 2011).

Thereby, the conversion of prochiral ketones (acetophenone and 2hexanone) into chiral alcohols (1-phenylethanol and 2-hexanol) catalyzed by $\mathrm{ADH}$ in the presence of $\beta-\mathrm{NADH}$ using a membrane reactor was made by feeding the reactor alternately with acetophenone or 2-hexanone and ethanol (auxiliary substrate). The main result is presented in Figure 6.

Figure 6. Profiles on the Continuous Conversion in the Membrane Reactor Fed with 10mM Acetophenone (•) and 10mM 2-hexanone (•), using Ethanol $(10 \mathrm{mM})$ as the Co-substrate. Conditions of Reaction: $30^{\circ} \mathrm{C}$, Feeding Rate = $2 \mathrm{~mL} / \mathrm{h}$, UF-membrane $=500 \mathrm{Da}, 100 \mathrm{rpm}$ and $50 \mathrm{mM}$ Phosphate Buffer $[\mathrm{pH} 7.0$ (Ketone Solution) and pH 8.8 (Ethanol Solution)]. The Up-directed Arrows Indicate Ethanol Addition, whereas Down-directed Arrows Indicate Addition of Acetophenone or 2-hexanone

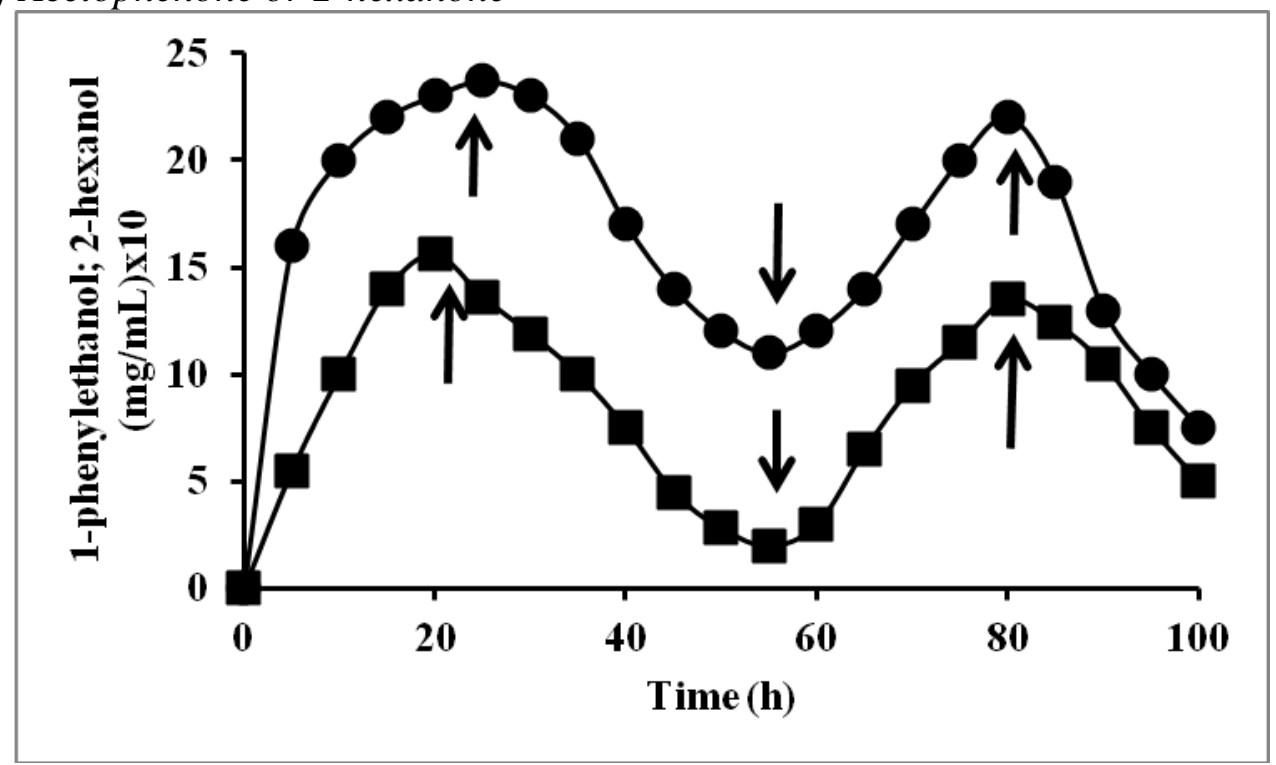


Figure 6 shows clearly that the ketone/alcohol conversion - in the present case acetophenone/1-phenylethanol or 2-hexanone/2-hexanol yield was $60 \%$ and $30 \%$, respectively - is a quite possible approach and the process deserves to be improved. When the ethanol is introduced into the reactor, a small volume of the outlet solution will contain both acetaldehyde and chiral alcohol (washed out as ethanol is introduced into the reactor). However, the separation of the aldehyde and the alcohol is easily made by fractionated precipitation, a unit operation well known by chemical engineers and/or chemists.

\section{Conclusions}

The data presented allows concluding that the yeast alcohol dehydrogenase (ADH) performed adequately on the reduction of acetophenone and 2hexanone as well as on the ethanol oxidation. The alcohols and ketones at concentrations of $0.1-1.0 \mathrm{mM}$ were also adequately measured by using potassium dichromate and 2,4-dinitro-phenylhydrazine reagents, respectively. The enzyme was sensitive to the ionic strength of the reaction medium, presenting higher activity in $50 \mathrm{mM}$ than $10 \mathrm{mM}$ phosphate buffer $(\mathrm{pH} 7.0)$. The highest $\mathrm{ADH}$ activity occurred at $50^{\circ} \mathrm{C}$ (acetophenone) and $40^{\circ} \mathrm{C}$ (2-hexanone). A 50mM-phosphate buffer solution of $\mathrm{ADH}\left(\mathrm{pH} \mathrm{7.0)} \mathrm{left} \mathrm{for} 24 \mathrm{~h}\right.$ at $40^{\circ} \mathrm{C}$ and $50^{\circ} \mathrm{C}$ had its overall activity diminished about $0.14 \%$ and $0.25 \%$ per hour, respectively. The overall conversions of acetophenone/1-phenylethanol and 2hexanone/2-hexanol through a batch process were $75 \%$ and $65 \%$, respectively. Besides, by alternating the addition of ketone (substrate) with ethanol (cosubstrate) into the membrane reactor operated under the continuous mode, the average yields were $60 \%$ to acetophenone and $30 \%$ to 2 -hexanone. Thereby, the continuous process may still be improved.

\section{Acknowledgments}

This work was financially supported by CNPq (Conselho Nacional de Desenvolvimento Científico e Tecnológico), Brazil. The Authors thank Philip Barsanti for his invaluable and constructive assessment of the manuscript.

\section{References}

Andreotti, D.Z., Tomotani, E.J., Vitolo, M. 2010. The use of dehydrogenases for regenerating $\beta$-nicotinamide adenine coenzymes through discontinuous and continuous processes. In Proceedings of the European Biomass Conference and Exhibition from Research to Industry and Markets(Lyon, France, May 03 - 07, 2010). Eta-Florence, Florence, 1367-1370.

Boshoff, A., Burton, M.H., Burton, S.G. 2003. Optimization of catechol production by membrane-immobilized polyphenol oxidase: a modeling approach. Biotechnol. Bioeng. 83 (Jan. 2003), 1-7. 
Vol. 2, No. 3 Vitolo et al.: Reduction of Prochiralic Ketones by NAD(H)-dependent...

Chen, P. 2008. A novel application of TPASD-MBR system to the pilot treatment of chemical synthesis-based pharmaceutical wastewater. Water Res.42 (Sep. 2008), 3385-3392.

Curcio, S., Calabró, V., Iorio, G. 2002. Monitoring and controlo f TMP and feed flow rate pulsatile operations during ultrafiltration in a membrane module. Desalination, 146 (Apr. 2002), 217-222.

Findrik, Z., Presecki, A.V., Vasic-Racki, D. 2007. Mathematical modeling of NADH oxidation catalyzed by new NADH oxidase from Lactobacillus brevis in continuously operated enzyme membrane reactor. J. Biosc. Bioeng. (Oct. 2007), 104, 275-280.

Fullbrook, P.D. 1996. Practical limits and prospects (kinetics). In Industrial Enzymology. Godfrey, T. and West, S., eds. $2^{\text {nd }}$ Edition, MacMillan Press LTD., New York, (1996), 503-540.

Ghalavand, Y., Hatamipour, M.S., Rahini, A. 2015. A review on energy consumption of desalination processes. Desalination and Water Treatment 54 (Dec. 2015), 1526-1541.

Goldberg, K.L. 2007. Biocatalytic ketone reduction - a powerful tool for the production of chiral alcohols - processes with isolated enzymes. Appl. Microbiol. Biotechnol. 76 (Jun. 2007), 237-248.

Hummel, W. 1990. Reduction of acetophenone to R(+)-phenylethanol by a new alcohol dehydrogenase from L.kefir. Appl. Microbiol. Biotechnol. 34 (Sep. 1990), 15-19.

Isarankura-Na-Ayudhya, S. 2007. Appropriate technology for the bioconversion of water hyacinth to liquid ethanol. EXCLI Journal 6 (Mar. 2007), 167-176.

Lozano, P., Villora, G., Gómez, D., Gayo, A.B. 2004. Membrane reactor with immobilized Candida Antarctica lipase for ester synthesis in supercritical carbon dioxide. The Journal of Supercritical Fluids 29 (Nov. 2004), 121-128.

Lutz, S., Rao, N.N., Wandrey, C. 2006. Membranes in biotechnology. Chem. Eng. Technol. 29 (Feb. 2006), 1404-1415.

Martin-Pascual, J., Leyva-Diáz, J.C., Hontoria, E. 2015. Effects of temperature on the permeability and critical flux of the membrane in a moving bed membrane bioreactor. Desalination and Water Treatment 53 (Jun. 2015), 3439-3448.

Müller, P. (2010). Enantioselective enzymatic reduction of prochiral ketones in onephase and two-phase system. PhD. Thesis, RWTH-Aachen University (Germany) (Mar. 2010), 1-165.

Purich, D.L. 2010. Enzyme kinetics . Academic Press, London, UK.

Purnendu, K.D., Zhang, G., Schulze, S., Marx, J.N. 1994. Measurement of carbonyl compounds as the 2,4-dinitrophenylhydrazone: reaction mechanism and an automated measurement system. Anal. Chem. 66 (Jul. 1994), 1965-1970.

Riebel, A.S. 2003. Cofactor regeneration of both $\mathrm{NAD}^{+}$from NADH and NADP ${ }^{+}$ from NADPH:NADH oxidase from L. sanfranciscensis. Adv. Synth. Catal. 345 (Jan. 2003), 707-712.

Sheu, D.C., Duan, K.J., Cheng, Y. 2002. Continuous production of high-content fructooligosaccharides by complex cell system, Biotechnol. Prog., 18 (Nov. 2002), 1282-1286.

Slominska, L., Szostek, A., Grzeskowiak, A. 2002. Studies on enzymatic continuous production of cyclodextrins in an ultrafiltration membrane bioreactor. Carbohydrate Polym. 50 (Jun. 2002), 423-428. 
Taraboulsi-Jr, F.A., Yoriyaz, E.J., Vitolo, M. 2014. Note on UV absorption by $\beta$ nicotinamide adenine coenzymes. Int. J. Adv. Pharm. Sci. 5 (Apr. 2014), 20022006.

Tomotani, E.J. and Vitolo, M. 2007. Production of HFS using immobilized invertase in a membrane reactor. J. Food Eng. 80 (Oct. 2007), 662-667.

Tomotani, E.J. and Vitolo, M. 2011. The use of amembrane reactor for the $\mathrm{NAD}(\mathrm{H})$ continuous regeneration catalyzed by $\mathrm{NAD}(\mathrm{H})$-dependent alcohol dehydrogenase through the substrate-coupled procedure. In Proceedings of the European Biomass Conference and Exhibition from Research to Industry and Markets (Berlin, Germany, June 06 - 10, 2011). Eta-Florence, Florence, 1015-1018.

Van der Donk, W.A. and Zhao, H. 2003. Recent development in pyridine nucleotide regeneration. Curr. Opinion Biotechnol. 14 (Mar. 2003), 421-426.

Wildeman, S.M.A., Sonke, T., May, O. 2007. Biocatalytic reductions: Lab curiosity to "first choice". Acc. Chem. Res. 40 (Jul. 2007), 1260-1266.

Yoriyaz, E.J. and Vitolo, M. 2014. Feasibility on using the membrane reactor for sucrose hydrolysis. World J. Pharm. Sci. 2 (Mar. 2014), 66-72.

Zanon, J.P., Peres, M.F.S., Gattás, E.A.L. Colorimetric assay of ethanol using alcohol dehydrogenase from dry baker's yeast. 2015. Enz. Microbial Technol. 69 (Mar. 2015), 1-5. 
